\title{
The effect of dolomite, limestone and zinc oxide as feed additives on utilization of organic matter and minerals by young fattening cattle*
}

\author{
Stefania Kinal and J. Preś \\ Department of Animal Nutrition and Feed Sciences, \\ Wroclaw Agricultural University \\ Norwida 25/27, 50-375 Wroclaw, Poland
}

(Received 23 December 1994; accepted 22 August 1995)

\section{ABSTRACT}

Studies on the balance and digestibility of organic matter and minerals were carried out on 32 young Black-and-White bulls, divided into 8 groups, fed maize silage with rapeseed oil meal. Control group did not receive any mineral supplement while the rations of the experimental animals were supplemented with sodium phosphate and either limestone or local dolomites (Skalpasz or Dolopasz). Both control and experimental rations were fed either unsupplemented or supplemented with zinc oxide.

The addition of zinc oxide and the Skalpasz dolomite raised organic matter and fibre digestibility as well as nitrogen retention. The addition of sodium phosphate and dolomites increased $(\mathrm{P} \leqslant 0.01)$ the absorption of $\mathrm{Ca}, \mathrm{Mg}$ and $\mathrm{P}$.

During the 180 day period of fattening 120 young bulls with a initial weight of $220 \mathrm{~kg}$, daily live weight gains of the animals receiving dolomite-supplemented rations were 11 and $15 \%$ higher than in the control group.

KEY WORDS: fattening cattle, dolomite, limestone, zinc oxide, digestibility

\section{INTRODUCTION}

In addition to protein and carbohydrates, minerals play an important role in growth and physiological functions, i.e. in productivity. The requirements for

* This study was supported by the Polish Scientific Research Committee (KBN) (Project $\mathrm{N}^{0}$ 5S 30504505 ) 
macro- and microelements in growing animals depend on endogenous losses, current demand to cover body weight gain and the mutual proportions and availability of elements (Cromwell, 1980; Braithwaite, 1983, 1985; Martz et al., 1990; Kruczyńska, 1992;).

The requirements of highly productive animals for minerals are so high that it is necessary to supplement the feeds of young growing cattle with them (Pallauf, 1983a,b; Kleczkowski, 1988; Saba et al., 1988; Żarski, 1988; McDowell, 1992; Couzy et al., 1993; Kruczyńska, 1993). In practice it is necessary to supplement mineral deficits in rations by adding the appropriate mineral mixtures or processed minerals (limestone, dolomites) as well as by-products of the mining industry (magnesium or zinc oxide).

Higher digestion of structural feed carbohydrates can be expected as the result of improved growth conditions for ruminal cellulolytic bacteria due to the buffering properties of dolomites (Kinal et al., 1994). According to Kennedy et al. (1993) ruminal bacteria accumulate large amounts of zinc both on the surface and inside the cell. This points to the positive effect of zinc oxide on the digestibility of organic feed components.

The studies by Cromwell (1980) have shown that, in pigs, there is a large difference between utilization of calcium from limestone and dolomites. Taking into consideration the high calcium and magnesium concentration in dolomites, the question arises: how does feeding dolomite affect the availability of phosphorus and such microelements as zinc and copper in ruminants (Kirchgessner, 1986; Chester-Jones, 1989; Saba et al., 1990)? According to Kirchgessner et al. (1982), zinc is a component of sixteen metallo-enzymes, among which many play an important role in carbohydrate metabolism.

The aim of this study was to assess the effect of supplementing the diets of young fattening cattle with limestone, dolomites and zinc oxide on the utilization of organic matter and minerals.

\section{MATERIAL AND METHODS}

The balance-digestibility experiments were carried out on 32 young Black-and-White Lowland bulls with an average weight of $220-260 \mathrm{~kg}$, randomly assigned to 8 groups of 4 bulls each. The animals were kept in balance cages and fed twice daily with silage from maize harvested at the near wax-ripeness stage (approximately $27 \%$ dry matter) plus rapeseed oilmeal. The animals in control group I received no mineral supplements. The animals in experimental groups (II-VIII) received diets supplemented with either sodium phosphates and limestone, or dolomites. Both unsupplemented and supplemented rations were fed without or with zinc oxide as described in Table 1. The adaptation period 
TABLE 1

Rations composition in the balance experiment

\begin{tabular}{|c|c|c|c|c|c|c|c|c|}
\hline \multirow{2}{*}{ Feedstuff } & \multicolumn{8}{|c|}{ GROUPS } \\
\hline & I & II & III & IV & $\mathrm{V}$ & VI & VII & VIII \\
\hline Maize silage, $\mathrm{kg}$ & 15.0 & 15.0 & 15.0 & 15.0 & 15.0 & 20.0 & 20.0 & 15.0 \\
\hline Rapeseed oilmeal, kg & 0.5 & 0.5 & 0.5 & 0.5 & 0.50 & 0.5 & 0.5 & 0.5 \\
\hline Sodium phosphate, $\mathrm{g}$ & - & - & 33.0 & 33.0 & 32.0 & 20.0 & 20.0 & 32.0 \\
\hline Limestone, $\mathrm{g}$ & - & - & 63.0 & 63.0 & - & - & - & - \\
\hline Dolomite "Skalpasz", g & - & - & - & - & 125.0 & 100.0 & - & - \\
\hline Dolomite "Dolopasz", g & - & - & - & - & - & - & 125.0 & 125.0 \\
\hline $\mathrm{ZnO}, \mathrm{g}$ & - & 0.24 & - & 0.24 & - & 0.24 & - & 0.24 \\
\hline \multicolumn{9}{|l|}{ In the ration: } \\
\hline dry matter, $\mathrm{kg}$ & 4.5 & 4.5 & 4.5 & 4.5 & 4.5 & 5.8 & 5.8 & 4.5 \\
\hline crude protein, $\mathrm{g}$ & 465 & 465 & 465 & 465 & 465 & 540 & 540 & 465 \\
\hline net energy, MJ & 21.6 & 21.6 & 21.6 & 21.6 & 21.6 & 27.8 & 27.8 & 21.6 \\
\hline $\mathrm{Ca}, \mathrm{g}$ & 16.7 & 16.7 & 41.0 & 41.0 & 43.5 & 47.8 & 48.1 & 43.5 \\
\hline$P, g$ & 17.4 & 17.4 & 23.2 & 23.2 & 23.0 & 24.9 & 24.9 & 23.0 \\
\hline $\mathrm{Mg}, \mathrm{g}$ & 11.6 & 11.6 & 11.6 & 11.6 & 24.9 & 26.2 & 28.0 & 24.9 \\
\hline $\mathrm{Na}, \mathrm{g}$ & 2.0 & 2.0 & 16.3 & 16.3 & 15.9 & 11.3 & 11.3 & 16.0 \\
\hline $\mathrm{Zn}, \mathrm{mg}$ & 107.4 & 299.4 & 107.4 & 299.4 & 112.0 & 328.6 & 137.3 & 304.2 \\
\hline $\mathrm{Cu}, \mathrm{mg}$ & 24.5 & 24.5 & 24.5 & 24.5 & 24.5 & 32.1 & 32.2 & 25.1 \\
\hline
\end{tabular}

Dolomite "Skalpasz", Służejów - near Kłodzko

Dolomite "Dolopasz", Sucha Góra - near Bytom

lasted 4 weeks, faeces and urine collection 5 to 7 days. A 10\% HCL solution was used to preserve faeces $(10 \%)$ and urine $(5 \%)$ samples.

The fattening experiment was conducted for 180 days on 120 young Black-and-White Lowland bulls with an initial weight of $220 \mathrm{~kg}$. The animals were allotted to 4 groups, three replicates each, and fed maize silage, ground barley and rapeseed oilmeal. Limestone or local dolomites (Dolopasz and Skalpasz) were used as mineral supplements (Table 2).

Weight gain and feed intake were recorded monthly.

The nutrient content of feeds, faeces and urine were determined using conventional methods, minerals following mineralization in a mixture of concentrated nitric and perchloric acids by atomic absorption spectrometry using a Zeiss AAS-3 spectrometer. Phosphorus was determined by the vanadium-molybdenum method using a Spekol colorimeter.

At the end of the balance-digestibility and fattening experiment blood was sampled from the jugular vein and analyzed for urea, glucose and mineral content using kits from POCh Gliwice (Poland) and an AAS-3 atomic absorption spectrometer. 
TABLE 2

Rations composition for fattening bulls

GROUPS

\begin{tabular}{|c|c|c|c|c|}
\hline Fcedstuffs & I & II & III & IV \\
\hline Maize silage, $\mathrm{kg}$ & $20-22$ & $20-22$ & $20-22$ & $20-22$ \\
\hline Ground barley, kg & 1.0 & 1.0 & 1.0 & 1.0 \\
\hline Rapeseed oilmeal, kg & 0.5 & 0.5 & 0.5 & 0.5 \\
\hline Limestone, g & - & 50.0 & - & - \\
\hline Dolomite "Skalpasz", g & - & - & 80.0 & - \\
\hline Dolomitc "Dolopasz", g & - & - & - & 90.0 \\
\hline \multicolumn{5}{|l|}{ In the ration: } \\
\hline dry matter, kg & $7.3-7.9$ & $7.3-7.9$ & $7.3-7.9$ & $7.3-7.9$ \\
\hline crude protein, $\mathrm{g}$ & $786-836$ & $786-836$ & $786-836$ & $786-836$ \\
\hline net energy, MJ & $34.4-36.9$ & $34.4-36.9$ & $34.4-36.9$ & $34.4-36.9$ \\
\hline Ca.g & $28.0-30.4$ & $46.7-49.2$ & $47.4-47.8$ & $46.9-49.3$ \\
\hline$P, g$ & $27.4-29.2$ & $27.4-29.2$ & $27.4-29.2$ & $27.4-29.2$ \\
\hline $\mathrm{Mg}, \mathrm{g}$ & $9.9-10.5$ & $9.9-10.5$ & $21.7-22.3$ & $20.2-20.8$ \\
\hline $\mathrm{Zn}, \mathrm{mg}$ & $281.8-302.0$ & $281.0-302.0$ & $284.5-302.5$ & $284.3-305.3$ \\
\hline $\mathrm{Cu}, \mathrm{mg}$ & $38.0-41.0$ & $38.0-41.0$ & $38.4-41.4$ & $38.4-41.4$ \\
\hline
\end{tabular}

The results were subjected to statistical analysis using variance analysis and Duncan's multiple range test (Ruszczyc, 1978).

\section{RESULTS AND DISCUSSION}

Table 3 presents the mineral content of feeds and additives. The Dolopasz dolomite contained more calcium, magnesium and zinc than Skalpasz. The copper content in both dolomites was similar. The $\mathrm{Ca}$ and $\mathrm{Mg}$ contents were similar to that reported in earlier studies (Kinal et al., 1994; Zyzak, 1994). In addition to $\mathrm{Ca}$ and $\mathrm{Mg}$ the dolomites contained small amounts of microelements in amounts similar to those reported in papers by Saba et al. (1990) and Zyzak et al. (1994).

The digestibility of crude protein in rations was similar in all groups (Table 4). The addition of zinc oxide to the diet of group II increased digestibility $(\mathrm{P} \leqslant 0.01)$ of organic matter, crude fibre and $\mathrm{N}$-free extractives. Supplementation of the basic ration with limestone and sodium phosphate increased $(P \leqslant 0.05)$ only the digestibility of crude fibre, while the addition of zinc oxide to the same ration (group IV) increased $(\mathrm{P} \leqslant 0.01$ ) organic matter, crude fibre and $\mathrm{N}$-free extractives digestibility. Increased digestibility of these nutrients was also noted following the addition of Skalpasz, sodium phosphate and zinc oxide, similarly as in 
崫

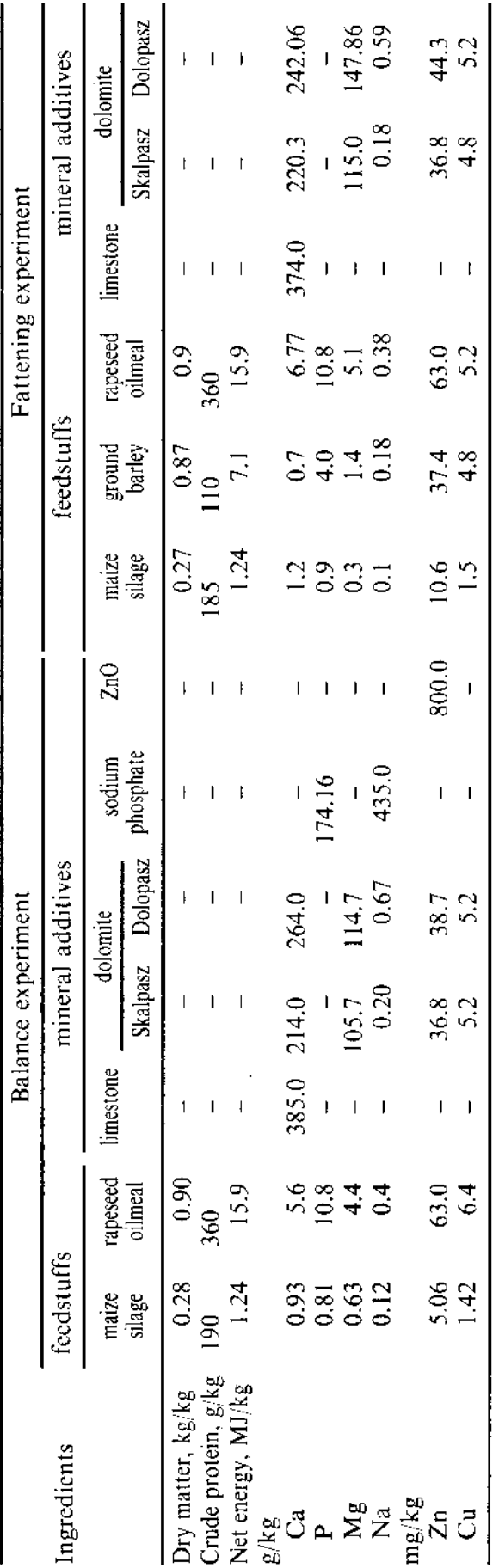

$\underset{\frac{1}{3}}{\frac{1}{5}}$

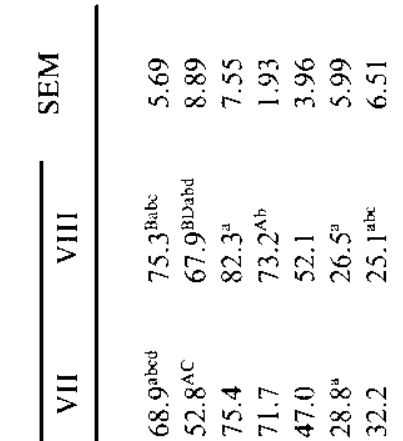

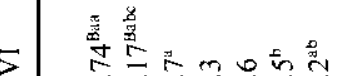
खिंவ் 苋总

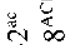

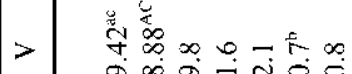

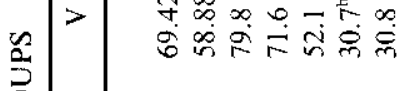

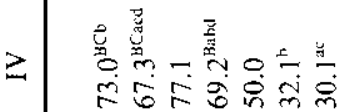

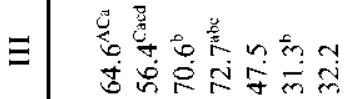

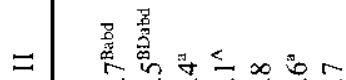

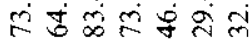

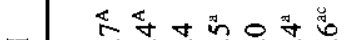

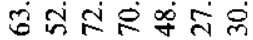


previous experiments (Kinal et al., 1994). The addition of Skalpasz and zinc oxide (group IV) raised $(\mathrm{P} \leqslant 0.01)$ organic matter and crude fibre digestibility in comparison with the control group.

Nitrogen retention was significantly higher in experimental groups III to VI than in controls.

Supplementation of the calcium and magnesium deficiency of the feed with the Dolopasz dolomite (group VII) did not have a marked effect on nutrients digestibility or nitrogen balance, while adding zinc oxide along with this dolomite (group VIII) significantly $(\mathrm{P} \leqslant 0.01)$ increased organic matter, crude fibre and $\mathrm{N}$-free extractives digestibility.

In summarizing the results, it can be said that the addition of zinc oxide to a deficient diet (group II) and to diets containing dolomites and sodium phosphate (groups VI and VIII) increased the digestibility of organic matter, crude fibre and $\mathrm{N}$-free extractives. Taking into account the role played by zinc in carbohydrate metabolism (Kirchgessner et al., 1982), the improvement of carbohydrate utilization by young fattening cattle was according to expectation.

Adding limestone (group III and IV) and dolomite (group V and VI) to the rations significantly raised nitrogen retention.

Significant improvement of carbohydrate digestibility and nitrogen retention was found when Skalpasz dolomite and sodium phosphate were added to the feed (group V). Kinal et al. (1994) obtained similar results in experiments on sheep. No effect of adding Dolopasz dolomite was found. However, when it was supplied with zinc oxide, carbohydrate digestibility improved.

The results showing absorption and retention of minerals (Table 5) indicate that when the basic diet was supplemented with zinc oxide (group II), no significant changes in mineral absorption or retention occurred, except the expected increased absorption and retention of zinc. However, the addition of limestone and sodium phosphate to this diet (group III) led to a significant rise in absorption and retention of calcium. Sodium retention also rose notably $(\mathrm{P} \leqslant 0.05)$. Supplementing the diet with Skalpasz dolomite and sodium phosphate (group $\mathrm{V}$ ) increased calcium and sodium absorption and retention $(\mathrm{P} \leqslant 0.01)$ as well as absorption of phosphorus and magnesium. The addition of zinc oxide to this diet (group VI) did not lead to additional significant changes. Supplementing the basic diet with Dolopasz dolomite and sodium phosphate (group VII) caused a rise, similarly as in group $\mathrm{V}$, in absorption and retention of calcium and sodium as well as increased retention of magnesium and phosphorus. When this diet was additionally supplemented with zinc oxide, the absorption and retention of zinc rose $(\mathrm{P} \leqslant 0.01)$.

In summarizing these results (Table 5), it can be concluded that supplementing a calcium- and phosphorus-deficient diet with limestone and sodium phosphate significantly improved calcium and phosphorus absorption and balance. The 


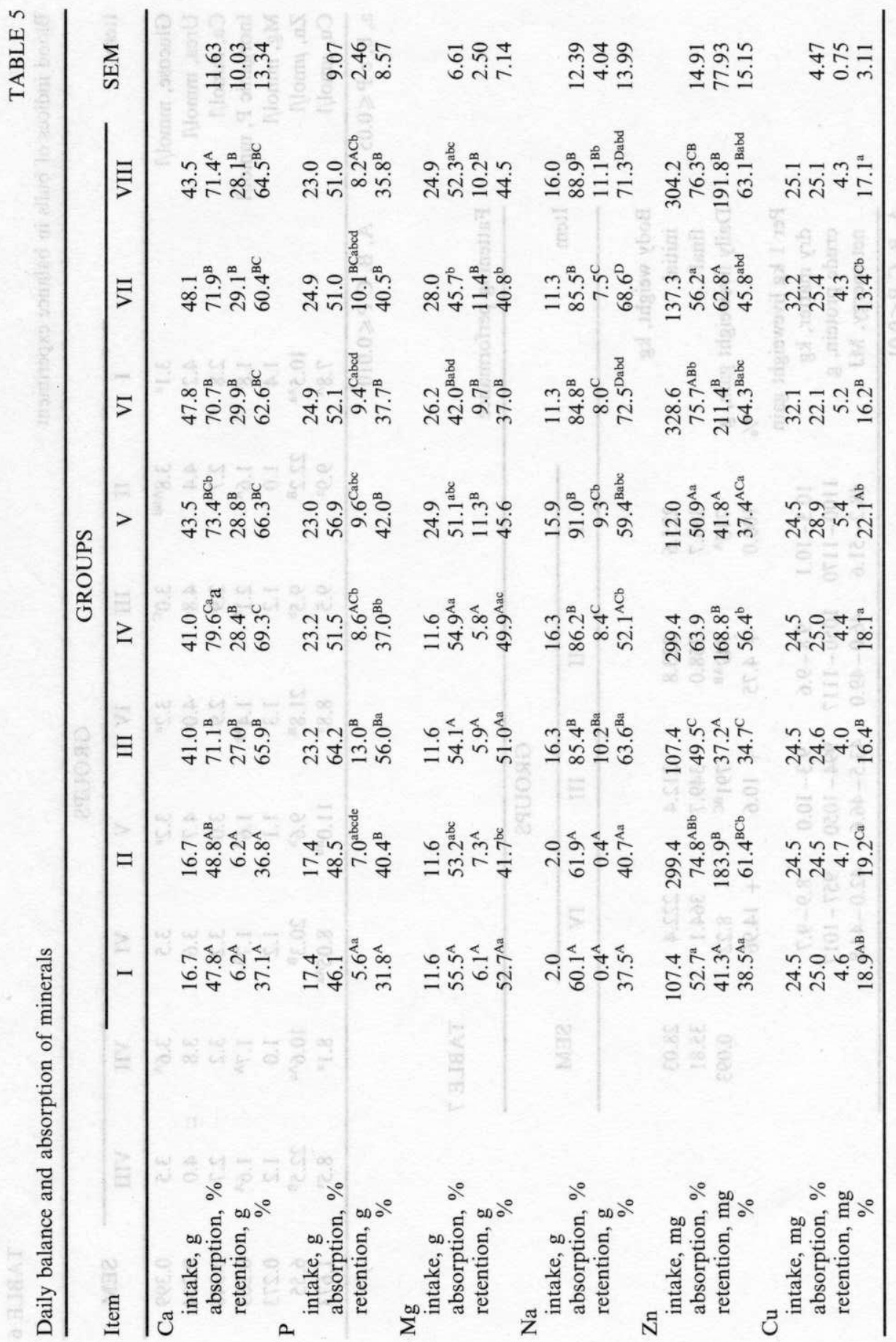




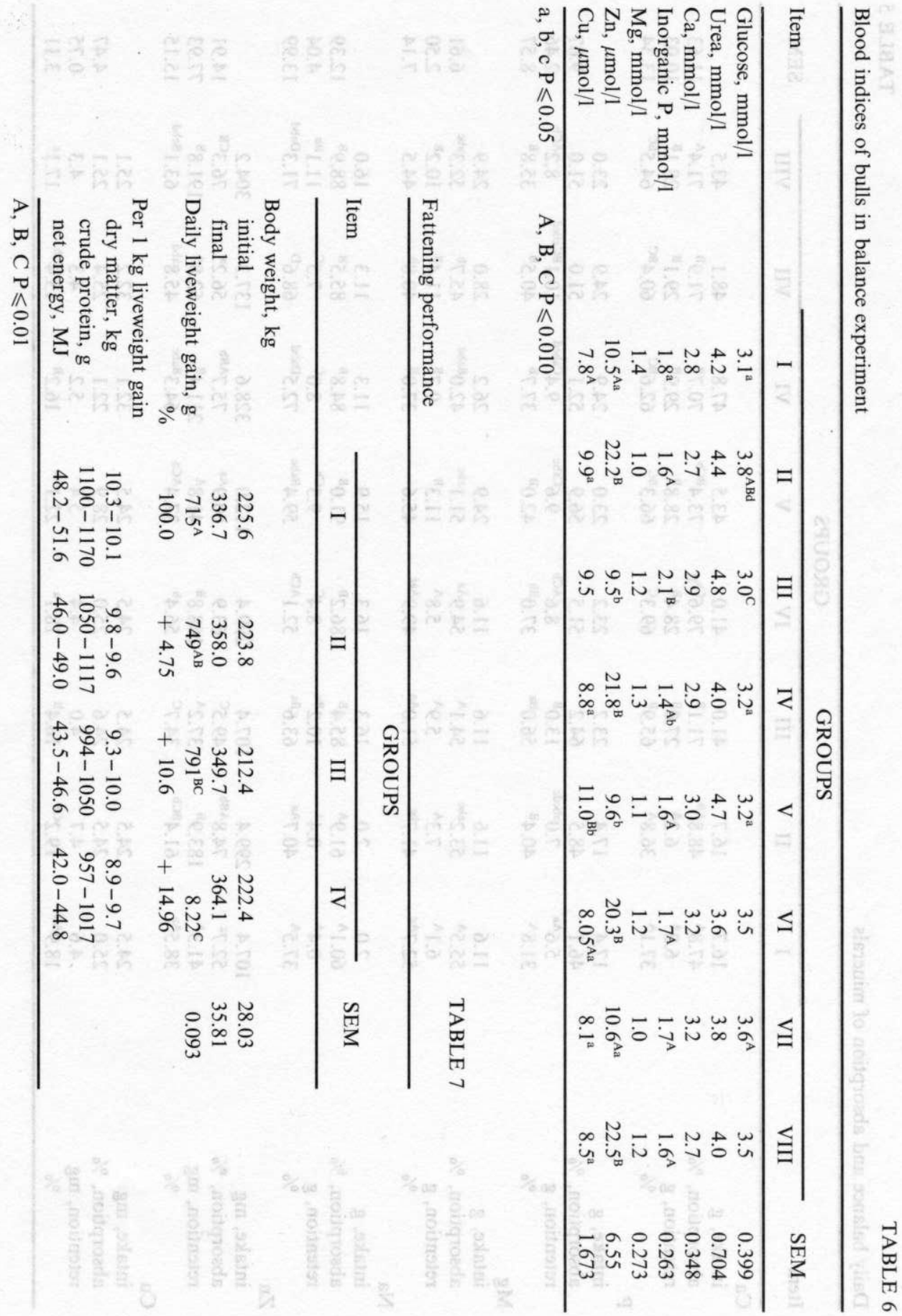


addition of dolomites and sodium phosphate to the rations significantly $(\mathrm{P} \leqslant 0.01)$ improved $\mathrm{Ca}, \mathrm{P}$ and $\mathrm{Mg}$ balance. Cromwell et al. (1980) also point to the differences in utilization of calcium from limestone and dolomite.

In groups from IV to VIII, the $\mathrm{Ca}$ and $\mathrm{P}$ dietary levels were similar, therefore, so was the $\mathrm{Ca}$ to $\mathrm{P}$ ratio. Absorption of $\mathrm{Ca}$ was high and ranged from 71 to $79 \%$, while that of phosphorus was low, from 51 to $57 \%$. According to the AFRC (1991), cattle absorb about $68 \%$ of Ca. Intensive growth (deposition of approximately $30 \mathrm{~g} \mathrm{~N}$ daily) may have also led to better $\mathrm{Ca}$ utilization by young fattening cattle in our experiment. An explanation for the lower phosphorus absorption can be sought in the higher level of zinc (the addition of $\mathrm{ZnO}$ ).

The addition of zinc oxide to the rations significantly increased only the absorption and retention of zinc. A certain excess of calcium introduced into the rations along with the dolomite did not affect these indicators. When limestone was added, a decline in the absorption and retention of this element was observed.

No effect of either of the dolomites or limestone was noted on the absorption and retention of copper (Table 7).

The blood glucose concentration rose considerably when zinc oxide was added to the feed (Table 6), which corresponds to the significant improvement in carbohydrate utilization in these groups. The urea, calcium and magnesium levels did not differ significantly among groups, while after adding dolomites and zinc oxide, the level of inorganic phosphorus declined. Significant differences were found among groups in the levels of zinc and copper $(P \leqslant 0.01)$. A distinct rise in the $\mathrm{Cu}$ level was observed when the Skalpasz dolomite was added to the basic feed along with sodium phosphate (group V), while adding both dolomites and zinc oxide (groups VI and VIII) caused a significant fall in the level of this element in the blood. In animals receiving zinc oxide, the serum $\mathrm{Zn}$ level rose. According to Mills (1987) the blood $\mathrm{Zn}$ level is a good indicator of its supply to the animal.

Different sources recommended different daily allowances of zinc: the ARC (1988) recommends $30 \mathrm{ppm}$, while the NRC (1988), AFRC (1991) and INRA (1988) about $50 \mathrm{ppm}$. In our experiments the $\mathrm{Zn}$ supply was higher and equaled 75-80 ppm.

In the fattening experiment, live weight gains of young bulls receiving limestone and dolomites in their feeds (Table 7) were higher $(P \leqslant 0.01)$ than in control (I); from $10 \%$ to $15 \%$ in the "dolomite" groups (III and IV), while only $5 \%$ in the limestone group (II). The body weight gains of the young bulls were not high, $700-800 \mathrm{~g}$, since an extensive fattening system was used. Among the studied biochemical parameters, only the glucose level was higher $(P \leqslant 0.01)$ in bulls from group IV, that received Dolopasz dolomite, than in the control group (Table 8). 
Blood incides of fattening bulls

GROUPS

\begin{tabular}{lccccc} 
& I & II & III & IV & SEM \\
\hline Glucose, mmol/1 & $2.4^{\mathrm{A}}$ & 2.7 & 2.8 & $3.0^{\mathrm{B}}$ & 0.44 \\
Urea, mmol/1 & 2.2 & 2.3 & 1.9 & 2.1 & 0.61 \\
$\mathrm{Ca}, \mathrm{mmol} / \mathrm{l}$ & 2.4 & 2.3 & 2.7 & 2.3 & 0.38 \\
Inorganic P, mmol/1 & 2.0 & 2.0 & 2.1 & 2.1 & 1.11 \\
$\mathrm{Mg}, \mathrm{mmol} / \mathrm{l}$ & 1.0 & 1.2 & 1.1 & 1.3 & 0.44 \\
$\mathrm{Zn}, \mu \mathrm{mol} / 1$ & 18.6 & 24.9 & 25.1 & 24.9 & 5.12 \\
$\mathrm{Cu}, \mu \mathrm{mol} / \mathrm{l}$ & 13.1 & 13.4 & 14.0 & 13.5 & 6.89 \\
\hline
\end{tabular}

A, B P $\leqslant 0.01$

\section{CONCLUSIONS}

- Supplementing the basic ration with zinc oxide led to increased digestibility of crude fibre and $\mathrm{N}$-free extractives, while zinc oxide along with dolomites or limestone increased digestibility of crude fibre.

- The addition of limestone or dolomites increased nitrogen retention, while dolomite plus sodium phosphate caused a significant rise in calcium, magnesium and phosphorus retention.

- When zinc oxide was added to the feed, the glucose and zinc levels in the blood rose; adding dolomite led to a rise in the blood copper level.

- The live weight gain of bulls receiving dolomite-supplemented feeds was 11 to $15 \%$ higher than that of control animals.

\section{REFERENCES}

AFRC. Agricultural and Food Research Council, 1991. Technical Committee on Responses to Nutrients, Report No. 6, A Reappraisal of the Calcium and Phosphorus Requirements of Sheep and Cattle. Nutr. Abstr. Rev., Ser. B, 61, 573-612

ARC. Agricultural Research Council, 1988. The Nutrient Requirements of Ruminant Livestock. CAB, London

Braithwaite G.D., 1983. Calcium and phosphorus requirement of the ewe during pregnancy and lactation. 1. Calcium. Brit. J. Nutr. 50, 711-722

Braithwaite G.D. 1985. Fndogenous faecal loss of phosphorus in growing lambs and the calculation of phosphorus requirements. J. Agric. Sci.. Camb. 105, 67-72

Chester-Jones H., Fountenot J.P., Veit H.P., Wcbb K.E.Ir., 1989. Physiological effects of feeding high levels of magnesium to sheep. J. Anim. Sci. 67, 1070

Cromwell G.L., 1980. Biological availability of phosphorus for pigs. Feedstuffs 38,529 
Couzy F., Keen C., Gershwin M.E., Mareschi J.P., 1993. Nutritional implications of the interactions between minerals. Progress Food Nutr. Sci. 17, 65-87

INRA-Institut National de la Recherche Agronomique, 1988. Alimentation des Bovins, Ovins et Caprins, INRA, Paris

Kennedy D.W., Craig W.M., Southern L.L., 1993. Ruminal distribution of zinc in steers fed a polysaccharide-zinc complex or zinc oxide. J. Anim. Sci. 71, 1281-1287

Kinal S., Korniewicz. A., Preś J., Paleczek B., 1994. Dolomites as a calcium and magnesium source in the feeding of growing sheep (in Polish). Mineral compounds in animal nutrition. Agricultural University of Poznań (Poland), pp. 201-206

Kinal S., Luczak W., Preś J., 1994. Chemical evaluation of various dolomites and limestone and their effect on utilization of $\mathrm{Ca}, \mathrm{P}, \mathrm{Mg}, \mathrm{Zn}, \mathrm{Cu}$ and organic components in feeding growing sheep (in Polish). Rocz. Nauk. Zoot. 21, 181-194

Kirchgessner M., 1986. Experimental results of trace element research relating to nutrition physiology. Proc. Soc. Nutr. Physiol. 1, 108-113

Kirchgessner M., Schwartz E., Weigand E., Roth H-P., 1982. Zum Stoffwechsel des Zinks im menschlichen und tierischen Organismus. In J. Staib (Editor). Spurenelemente Bedeutung für Chirurgie, Anästhesiologie und Intensivmedizin. Schattauer Stuttgart,New York, pp. 12-61

Kleczkowski M., 1988. Copper and zinc deficiency in cattle (in Polish). Proceedings XV Conference of Biochemistry. ZHW, Lomża

Kruczyńska H., 1992. Efficiency of mineral feeding of cows and calves in Wielkopolska region conditions (in Polish). Rocz. AR Poznań, Rozpr. Nauk. No. 231

Kruczyńska H., 1993. Cu, Mn and $\mathrm{Zn}$ concentration in natural feeds, feed mixtures and mineral supplements in relationship with nutrient requirement of cows (in Polish). Proceedings of VII Symposium: "Microelements in Agriculture"

Martz F.A., Belo A.T., Weiss M.F., Belyea R.L., 1990. True absorption of calcium and phosphorus from alfalfa and corn silage when fed to lactating cows. J. Dairy Sci. 73,1288-1295

McDowell L.R., 1992. Minerals in Animal and Human Nutrition. Acad. Press., New York

Mills C.F., 1987. Biochemical and physiological indicators of mineral status in animals: copper, cobalt and zinc. J. Anim. Sci. 65, 1702-1711

Pallauf J., 1983a. Bedarfsgerechte Versorgung des Rindes mit Mineralstoffen und Spurenelementen im Hinblick auf Gesundheit, Fruchtbarkeit und Leistung. Teil 2. Kraftfutter 7. 290-294

Pallauf J., 1983b. Bedarfsgerechte Versorgung des Rindes mit Mineralstoffen und Spurenelementen im Hinblick auf Gesundheit, Fruchtbarkeit und Leistung. Teil 2. Kraftutter 8, 320-328

Ruszczyc Z., 1978. Methodology of Experiments with Animals (in Polish). PWRiL, Warszawa

Saba L., Białkowski Z., Klocek B., Niedźwiadek T., Różaniecka K., 1988. Study on mineral status in young fattening cattle on mineral mixtures application (in Polish). Rocz. Nauk. rol. B. 104 (3), $39-50$

Saba L., Wójcik S., Bis-Wencel H., 1990. The effect of mineral mixtures with dolomite on the level of macro and microelements in the cows serum and hair (in Polish). Ann. UMCS VIII, 22, 181-189

Simek M., Dvorak R., Zendulka I., Benkovic A., 1990. Nutritional value and biological utilization of magnesium $(\mathrm{Mg})$ and calcium $(\mathrm{Ca})$ of dolomites. Mengen- und Spurenelemente 10, Arbeitstag, D12. 1990, Leipzig. 2; 473-478

Zyzak W., Brzóska F., Michalec J., Brzóska B., 1994. Biological availability of magnesium from dolomite limestone and magnenite. Mincral Compounds in Animal Nutrition. Agricultural University of Poznan (Poland), pp. 207-210

Żarski T.P., 1988. Recognition and evaluation of different methods of prevention and elimination of mineral deficiency in breeding ruminants and ruminants at liberty. Rozpr. Monogr. SGGW-AR Warszawa, pp. 1-104 


\section{STRESZCZENIE}

Wplyw dodatku dolomitów, kredy i tlenku cynku na wykorzystanie składników organicznych i mineralnych przez mlode bydlo opasowe

Badania bilansowo-strawnościowe składników organicznych i mineralnych przeprowadzono na 32 buhajkach ncb, podzielonych na 8 grup i żywionych kiszonką z. kukurydzy z dodatkiem poekstrakcyjnej śruty rzepakowej. Dawki pokarmowe zwierząt grup doświadczalnych uzupełniano fosforanem sodu z dodatkiem kredy lub rodzimych dotomitów (Skalpasz lub Dolopasz). Dawkę kontrolną i doświadczalne skarmiano bez lub z dodatkiem tlenku cynku. Przy dodatku tlenku cynku i dolomitu Skalpasz zwiększyła się strawność substancji organicznej i włókna dawek oraz retencja azotu w porównaniu z grupą kontrolną. Dodatek dolomitów oraz fosforanu sodu zwiększył $(\mathrm{P} \leqslant 0.01)$ absorpcję $\mathrm{Ca}, \mathrm{Mg}$ i $\mathrm{P}$.

W 180-dniowym opasic 120 buhajków o początkowej masie ciała ok. $220 \mathrm{~kg}$ przyrosty dzienne zwierząt otrzymujących dodatek dolomitów do dawck pokarmowych byly o $11 \mathrm{i} 15 \%$ większe niż zwierząt kontrolnych. 